University of Nebraska - Lincoln

DigitalCommons@University of Nebraska - Lincoln

Using packrat middens to assess grazing effects on vegetation change

\author{
J. Fisher \\ Northern Arizona University, nightbloomingcactus@yahoo.com \\ Ken L. Cole \\ USGS Southwest Biological Science Center, ken_cole@usgs.gov
}

R.S. Anderson

Northern Arizona University, scott.anderson@nau.edu

Follow this and additional works at: https://digitalcommons.unl.edu/usgsstaffpub

Fisher, J.; Cole, Ken L.; and Anderson, R.S., "Using packrat middens to assess grazing effects on vegetation change" (2009). USGS Staff -- Published Research. 541.

https://digitalcommons.unl.edu/usgsstaffpub/541

This Article is brought to you for free and open access by the US Geological Survey at DigitalCommons@University of Nebraska - Lincoln. It has been accepted for inclusion in USGS Staff -- Published Research by an authorized administrator of DigitalCommons@University of Nebraska - Lincoln. 


\title{
Using packrat middens to assess grazing effects on vegetation change
}

\author{
J. Fisher ${ }^{\text {a }}$, K.L. Cole ${ }^{\mathrm{b}, *}$, R.S. Anderson ${ }^{\mathrm{c}}$ \\ a Environmental Sciences E Policy Program, Northern Arizona University, P.O. Box 5694, Flagstaff, AZ 86011, USA \\ ${ }^{\mathrm{b}}$ USGS Southwest Biological Science Center, P.O. Box 5614, Flagstaff, AZ 86011, USA \\ ${ }^{c}$ Environmental Sciences \& Policy, and Quaternary Sciences Programs, Northern Arizona University, P.O. Box 5694, Flagstaff, AZ 86011, USA
}

\section{A R T I C L E I N F O}

\section{Article history:}

Received 1 July 2008

Received in revised form

3 February 2009

Accepted 7 April 2009

Available online 22 May 2009

\section{Keywords:}

Desert grassland

Grazing effects

Grazing history

Packrat middens

Species diversity

\begin{abstract}
A B S T R A C T
Research on grazing effects usually compares the same sites through time or grazed and ungrazed sites over the same time period. Both approaches are complicated in arid environments where grazing can have a long undocumented history and landscapes can be spatially heterogenous. This work employs both approaches simultaneously by comparing grazed and ungrazed samples through both time and space using fossil plant macrofossils and pollen from packrat middens. A series of 27 middens, spanning from $995 \mathrm{yr}$ BP to the present, were collected from Glen Canyon in southeastern Utah, USA. These middens detail vegetation change just prior to, and following, the historical introduction of domesticated grazers and also compares assemblages from nearby ungrazable mesas. Pre-grazing middens, and modern middens from ungrazed areas, record more native grasses, native herbs, and native shrubs such as Rhus trilobata, Amelanchier utahensis, and Shepherdia rotundifolia than modern middens from grazed areas. Ordinations demonstrate that site-to-site variability is more important than any temporal changes, making selection of comparable grazed versus ungrazed study treatments difficult. But within similar sites, the changes through time show that grazing lowered the number of taxa recorded, and lessened the pre-existing site differences, homogenizing the resultant plant associations in this desert grassland. Published by Elsevier Ltd.
\end{abstract}

\section{Introduction}

Research on the effects of grazing usually compares sites either spatially or temporally. Spatial studies require the assumptions that the grazed and ungrazed sites were the same prior to the grazing, and that the ungrazed site was either never grazed or that the consequences of the historical grazing have since become insignificant. These assumptions are especially problematic in the southwestern US where local species distributions can be strongly influenced by the complex underlying geologic substrates and diverse topography. And, the slow recovery of plants to disturbance in these semi-arid ecosystems (Bowers et al., 1997; Lovich and Bainbridge, 1999) requires that the entire history of grazing be understood; yet reliable grazing records extend back for only a small portion of this time. Studies of changes through time must assume that the vegetation was not influenced by other temporal variables such as climate, succession, or invasive exotics.

This research, conducted within Glen Canyon National Recreation Area (NRA), focused on how grazing affected the plant associations of the Colorado Plateau along Cataract Canyon of the

\footnotetext{
* Corresponding author. Tel.: +1 928523 7767; fax: +1928 5569111.

E-mail addresses: nightbloomingcactus@yahoo.com(J. Fisher),ken_cole@usgs.gov (K.L. Cole), scott.anderson@nau.edu (R.S. Anderson).
}

Colorado River. In this project, we confront the assumptions of temporal and spatial homogeneity by employing two unique features of the Glen Canyon area: assemblages of fossil plant debris called packrat middens, and inaccessible, cliff-lined, ungrazable mesas (Tuhy and MacMahon, 1988). These features allowed us to simultaneously examine the effects of grazing through both time and space.

This study demonstrates an important tool that can be applied in many other situations where historical baseline and natural reference conditions are unclear. Although the fortuitous combination of fossil packrat middens and ungrazable mesas found at Glen Canyon NRA are rare, other areas often have overlooked paleoecological assets, such as deposits of fossil pollen and charcoal (Davis et al., 2002), opal phytoliths (Fisher et al., 1995), or even dehydrated dung (Mead et al., 1986). These resources can provide an historical depth to help understand areas where change can be too slow for observation within a human lifespan (Bowers et al., 1997).

\subsection{Packrat middens}

Most packrat midden studies have concentrated on the effect of climate change on major perennial plant species over tens of thousands of years (Betancourt et al., 1990). This study applied 
a novel approach by comparing plant community change in grazed versus ungrazed areas concentrating on just the last 1000 years. Because of the importance of the families Poaceae and Asteraceae in grassland histories, and the low frequency and difficult identifications of their macrofossils, these deposits required exceptional detail in their analysis. This is a new application for packrat midden studies and a unique approach to studying grazing effects.

Packrats (genus Neotoma) are nocturnal browsers that find shelter in caves, crevices, or under spiny plants. Next to their home they will create a midden, or garbage pile, out of collected objects partially barricading the nest entrance. Packrats collect not only their food plants but also any plant parts and other objects from the vicinity of their home base within a radius of $20-100 \mathrm{~m}$ (Cole, 1990). Packrats then urinate and defecate on this pile, and over time the urine crystallizes, forming a hard, indurated midden, sealing this protective barrier around the packrat's nest. In arid regions, middens in caves or under overhangs that are protected from moisture can survive far beyond 50,000 years (Betancourt et al., 1990). Modern middens typically are not yet consolidated, being essentially debris piles of loose twigs, pellets, and finer plant material collected by the packrat.

Dating fossil middens only a few hundred years of age is problematic. Samples post-dating 1950 AD produce distinctively high values due to atmospheric testing of nuclear weapons. But samples dating between about 1750 and 1950 AD can be statistically indistinguishable from each other. As a result, this study required the collection of midden deposits estimated to be between 300 and 1000 years in age based upon subjective field criteria of hardness, geomorphic context, smell, and preservation. The actual ages are then determined through radiocarbon dating. Middens yielding radiocarbon ages between the pre-settlement (pre-1750 AD) and post-settlement (pre-1950 AD) periods are then classified as "transitional" in age.

Plant macrofossils such as seeds, twigs, fruits, and flowers are the most commonly analyzed fossil remains in middens. The excellent preservation of these plant parts, which have been mummified within the matrix of packrat urine, usually allows their identification to the genus or species level. Pollen is also well-preserved in middens, and can be useful for vegetation reconstructions (Anderson and Van Devender, 1991). Pollen and macrofossils each tell a different story about the paleobotanical record of an area. Because wind-blown pollen is more widely dispersed, pollen grains can represent a more regional picture of the past vegetation. Macrofossils, which usually enter the midden by being carried in by the packrat, show a more detailed picture of plants growing immediately adjacent to the midden. Because they represent different source areas and emphasize different taxonomic perspectives, fossil pollen and plant macrofossils compliment each other by showing slightly different views of the same paleoenvironment.

\subsection{Description of study sites}

Glen Canyon (NRA) is located in southeastern Utah and northern Arizona along the Colorado River as it cuts across the Colorado Plateau, an uplifted Plateau encompassing the Four Corners Region of the Southwest (Fig. 1). Glen Canyon NRA encompasses 500,540 ha with an elevational range from 940 to $2300 \mathrm{~m}$. Average annual precipitation (1970-1999 AD) is modeled to be about $23 \mathrm{~cm}$ (PRISM) at the main study sites from Cove Canyon to Waterhole Flat between 1600 and 1640 m elevation. About 20\% of this precipitation falls during the winter months (DJF). Following an arid foresummer in May and June, most of the annual precipitation (38\%) falls during the late summer monsoon months (JAS). Mean monthly high temperatures in July are about $34^{\circ} \mathrm{C}$ while January lows are about $-7^{\circ} \mathrm{C}$.

Horses, sheep, goats, and cattle were introduced into the Southwestern USA by Spanish colonists in the 16th Century (Underhill, 1971) and were quickly adopted for use by Native Americans. They spread to the indigenous tribes of the Colorado Plateau and Great Basin and were abundant by the 1800s (Cole et al., 1997; Knapp, 1996). By the 1840s severe grazing impacts on grasslands from the expanding sheep herds of the Navajo Nation were reported (Bailey and Bailey, 1986) which may have caused a drop in fire frequencies as early as 1829 AD (Savage and Swetnam, 1990). Grazing of both cattle and sheep was especially intense on the open range between 1870 and 1890 AD (Topping, 1997). Cattle grazing then continued throughout the 20th Century at a more moderate rate until it ceased in this study area soon after the completion of this project.

Over 800 species of plants have been recorded within Glen Canyon NRA and the Utah Heritage Program lists 18 species as 'rare' (Flowers, 1959; National Park Service, 1999). Native ungulate grazers in the NRA include mule deer (Odocoileus hemionus), pronghorn (Antilocapra americana), desert bighorn sheep (Ovis canadensis) and Rocky Mountain elk (Cervus elaphus). Other grazers include black-tailed jack rabbit (Lepus californicus) and desert cottontail (Sylvilagus audubonii). Bison (Bison bison), although not present today, may have occurred sporadically in this region since the Pleistocene (Johnson et al., 2005; Mead and Agenbroad, 1992).

Middens were collected from five areas within Glen Canyon NRA (Fig. 1) representing a range of grazing histories. All the selected sites were within the same grassland plant community as classified and mapped by the park (Spence et al., 1995) on similar sandstone substrates, and at similar elevations. Two recently grazed areas, Waterhole Flat (WF) and Cove Canyon (CC), are $10 \mathrm{~km}$ apart but at the same elevation and on the same geologic substrate. Middens from within the Cove Canyon area were further subdivided into three sub-sites of variable grazing intensity. CC-cow shade and CCcow tank are directly adjacent to water resources and had a high density of cattle dung. CC-cow shade is along a wash where high cliffs create a comfortable location sheltered from wind and sun. CC-500m from tank, as its name implies, is $500 \mathrm{~m}$ away from the water source and had a far lower density of cattle dung - a rough proxy for grazing intensity.

Middens were also located at Gandolf's Staircase (GS), an ungrazed site immediately between the Waterhole Flat and Cove Canyon areas. This site is on a bench just below the rim of Cataract Canyon of the Colorado River, and has steep vertical cliffs on all sides. Its only possible access is one route over $2 \mathrm{~km}$ from the nearest currently developed cattle tank over terrain too steep for cattle but possible for deer, bighorn sheep, or rock scrambling humans. Although a bone of a native mule deer was found at the site, the abundant and thick biological soil crusts showed no sign of visible impacts from any large animals. Further from these areas we located middens on two ungrazed mesas surrounded by vertical cliffs: 5381 Mesa (5 M) and Mazuki Point (MP) (Tuhy and MacMahon, 1988).

\section{Methods}

Forty-one packrat middens were collected over four years of field work. This cyclic pattern of field collection, lab dissection, and radiocarbon dating, followed by additional field collection, was essential for the refinement of subjective age estimations in the field as well as identification of unknown plant macrofossils. Of the midden collections, 12 were modern debris piles, 14 were presettlement fossil middens, one had a transitional age, and 14 were fossil middens ranging between 1000 and 17,000 years in age (to be 


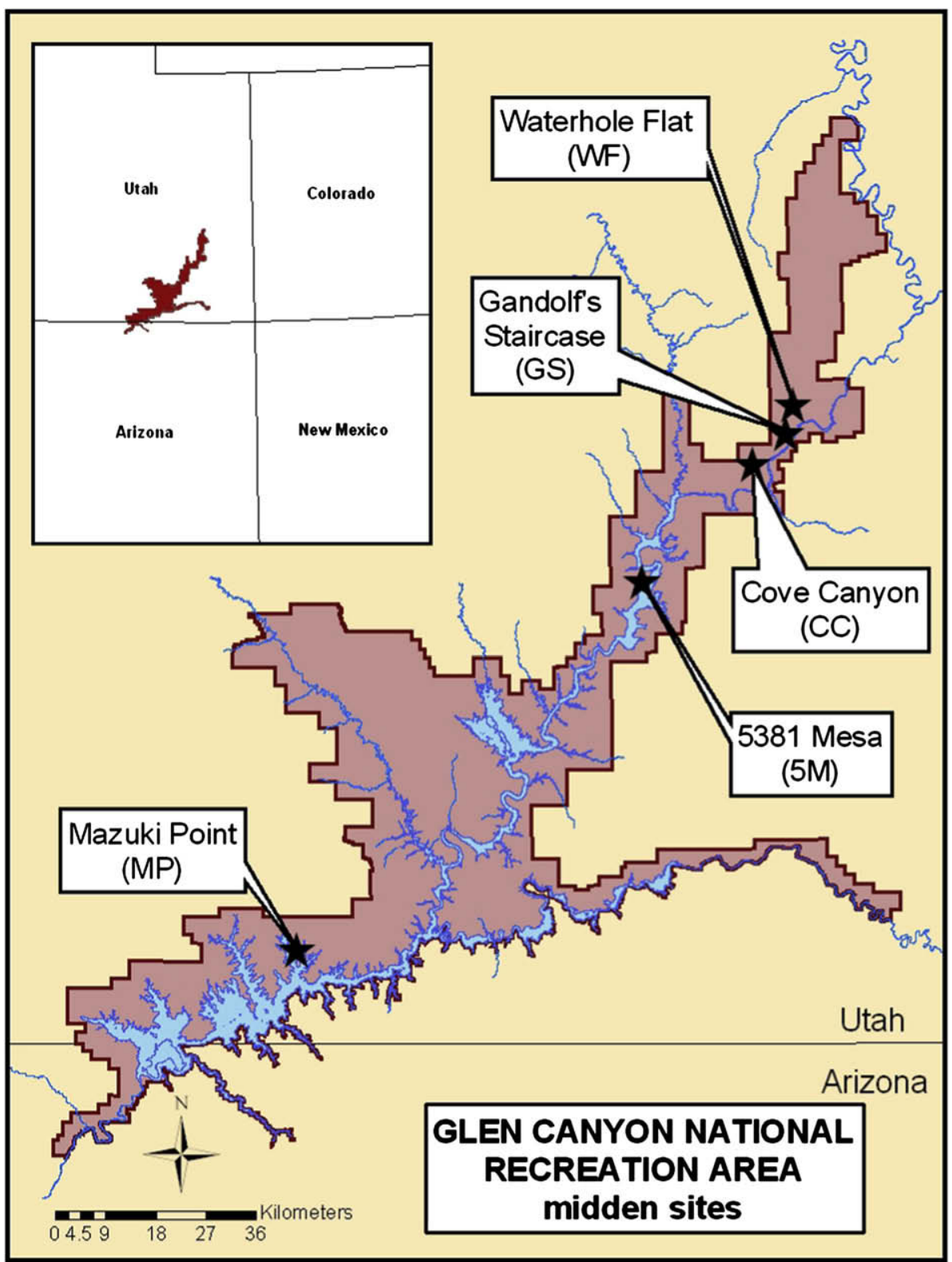

Fig. 1. Map of Glen Canyon NRA showing midden collection sites and their proximity.

reported separately). Radiocarbon analysis was usually conducted on each midden using conventional techniques on Neotoma pellets although nine additional samples were aged by applying Accelerator Mass Spectrometry (AMS) analysis on individual macrofossils. AMS techniques allow the dating of samples weighing only 3-10 mg.

The modern debris piles were judged to be currently active as evidenced by fresh plant parts, which were usually still green or yellowish, and/or post-1950 AD radiocarbon ages. Efforts were made to include all size fractions in these modern collections rather than just the large twigs so that they resembled the composition of fossil middens as much as possible.

The modern vegetation was quantified for comparison with the modern midden collections in several areas using circular plant plots. Each plot consisted of a circle extending $14 \mathrm{~m}$ outward from the midden collection site. All individuals were counted and measured within this plot, providing quantification of the areal cover and density for each species tabulated.
Our methods were adjusted to maximize the recovery and identification of tiny Poaceae florets and Asteraceae seeds since these were the most important taxa for the study of the grazing effects. Fossil middens were collected and prepared following methods similar to those described in Cole et al. (1997) using smaller samples than have often been used (Betancourt et al., 1990). The indurated midden samples were selected from fossil-rich layers, and were usually under $500 \mathrm{~g}$. Once disaggregated and washed in the laboratory, the resulting plant macrofossil matrix, minus the urine, rocks, and fecal pellets, was usually under $200 \mathrm{~g}$. These smaller sample sizes minimize contamination between layers of different ages, allow detailed quantification of the smallest size fossils, and remove as little as possible from the field localities where they are the most safely curated.

The middens were disaggregated and rinsed using only 41 of water and this rinse water was captured and used for the pollen sample. The pollen was extracted and analyzed from the rinse water for 11 middens reported here using standard extraction and 
analysis techniques (Fægri and Iversen, 1989). After extraction of the pollen sample, the resulting plant matrix was further washed and collected on a $0.5 \mathrm{~mm}$ screen. After drying, this matrix was weighed and examined under a $20 \times$ dissecting microscope, and individual taxa were sorted into glass vials. These weight and fluid measurements allow calculation of both plant macrofossil and pollen concentrations so that middens of different size can be more equitably compared. Plant species nomenclature is from the Integrated Taxonomic Information System (http://www.itis.usda.gov/ index.html).

\subsection{Multivariate ordinations of change}

Trends of change for plant associations were analyzed using multivariate ordinations. Detrended Correspondence Analysis (DCA) was applied to compare the effects of spatial and temporal variability between samples based upon their plant fragment concentrations. This technique not only allows display of the samples relative to each other, but also simultaneously the plant species and loading factors responsible for distinguishing between samples. Furthermore, the DCA axes are scaled in units of species turnover (Gauch, 1982), allowing quantification of the amount of vegetation change between assemblages.

\section{Results}

\subsection{Comparison of modern vegetation and modern middens}

Table 1 contrasts the modern vegetation measurements at two plots with modern middens from those plots. These comparisons aid in understanding how different plant species are represented in fossil middens. Dominant species are typically represented by a high number of identifiable specimens (NISP) and infrequent species by low NISP. Records of species absence, although more problematic than presence with individual midden assemblages, also seem to be accurately reflected using several assemblages (Nowak et al., 2000). But, the NISP totals do not directly correspond to species cover, density, or relative importance values, and these different measures of the same modern vegetation values do not directly correspond with each other as they are all different methods for quantifying vegetation amounts (Spaulding et al., 1990). But in terms of representing the dominant species of a specific area, the midden is very analogous to the species dominance and number of species found in a small plot such as those on Table 1.

The NISP values are influenced by several factors such as the abundance of each species, the number of identifiable specimens produced by that species, the distance to the plant, and packrat's desire and ability to transport those specimens to the midden. Species present within only a couple of meters distance are well represented in a midden, possibly from debris shed from the plant as much as the packrats collecting (K. Cole, unpublished data). Species producing a very high number of identifiable specimens include Juniperus, as its twigs easily fragment, multiplying into even higher numbers of easily identifiable specimens. Conversely, species such as Populus produce only a limited number of poorly identifiable twigs and very rarely, leaves. Species that are packrat food items (Juniperus and Opuntia) are often transported longer distances and are very commonly found.

Comparisons between middens, such as those shown in Table 1 , suggest that while Juniperus likely will be recorded if a tree is within $50 \mathrm{~m}$, Pinus edulis is not usually represented if the nearest tree is greater than $30 \mathrm{~m}$ distant. Only one seed and one needle of $P$. edulis were found in a modern midden $28 \mathrm{~m}$ from the nearest tree, while none were found in a midden $80 \mathrm{~m}$ from the nearest tree.
The midden assemblage also incorporates collections through time. Although one-time measurement of a plant plot likely will not reveal seasonal herbs not present at the time of measurement, they are more likely to be found within the midden. The modern midden probably incorporates specimens of nearby plants present over the last couple of years, while a fossil midden layer may incorporate plants from over a decade or more. The number of years represented within a fossil midden cannot be precisely determined since middens differ greatly in their rate of deposition and because the statistical error in radiocarbon samples is usually a century or more. Thus, two samples of identical age can yield radiocarbon ages 100 years apart.

\subsection{Midden ages and macrofossils}

Fourteen middens represented the pre-settlement period, with ${ }^{14} \mathrm{C}$ ages ranging from $995 \pm 65 \mathrm{yr} \mathrm{BP}$ to $220 \pm 45 \mathrm{yr} \mathrm{BP}$. The two most recent radiocarbon ages, $220 \pm 45 \mathrm{yr} \mathrm{BP}$ and $250 \pm 45 \mathrm{yr} \mathrm{BP}$ have less than a $15 \%$ probability of post-dating $1750 \mathrm{AD}$ once converted to calendar years (Stuiver and Reimer, 1993). One large debris pile was of transitional age - CC-1, containing both presettlement (pre-historic corn cob) and post-settlement (exotic species cheatgrass and pollen of Russian thistle) plant parts. Presettlement archaeological materials, especially corn cobs, are frequent in modern packrat debris piles in cliffs nearby archaeological corn storage sites. However, these items only impose a maximum possible age on the deposit as foraging packrats will readily collect any nearby fossil items as well as contemporaneous materials.

Ninety-eight different plant types were identified from the middens. Identification of this unusually high number of taxa was made possible through the fine sorting of the midden matrix, and extensive comparison of tiny plant fragments such as Poaceae florets and Asteraceae achenes with those from the regional flora. The most frequent and relevant taxa, representing less than half of the total types identified, are displayed in Figs. 2-4. The figures illustrate macrofossil concentration through time displayed on a logarithmic scale, which helps normalize the values and allows comparison between middens of different size.

\subsection{Pre-settlement time period}

Middens representing the pre-settlement period, from 1000 to $1750 \mathrm{AD}$, come from all sites except Mazuki Point. Blackbrush (Coleogyne ramosissima), ephedra (Ephedra spp.), prickly pear (Opuntia spp.), Bigelow's sagebrush (Artemisia bigelovii), fourwing saltbush (Atriplex canescens), winterfat (Krascheninnikovia lanata), broom snakeweed (Gutierrezia spp.), narrowleaf yucca (Yucca angustissima) (Fig. 2), pinyon pine (P. edulis), and Utah juniper (Juniperus osteosperma) (Fig. 3) were all dominant members of the plant associations found in these middens. Native grasses were frequently found through this time period, particularly Indian rice grass (Achnatherum hymenoides), needle and thread (Hesperostipa comata ssp. comata), galleta grass (Pleuraphis jamesii), and six weeks fescue (Vulpia octoflora) (Fig. 4). These middens averaged $19.1 \pm 5.4$ genera/midden.

Shadscale (Atriplex confertifolia) was found only in five middens, all near areas in Cove Canyon currently populated by shadscale. Rubber rabbitbrush (Ericameria nauseosa), skunkbush sumac $(R$. trilobata), and roundleaf buffaloberry (Sheperdia rotundifolia) were all seen frequently in the younger half of the series. Cheatgrass (Bromus tectorum), an introduced exotic, occurred in three middens in the later part of the series. In each case, no more than two spikelets were recorded, suggesting that these small plant parts were contaminants, incorporated into the midden after it was 
Table 1

The contents of two circular plant plots, $14 \mathrm{~m}$ in radius $\left(616 \mathrm{~m}^{2}\right)$, are compared with two modern midden collections taken from the center of each plot.

\begin{tabular}{|c|c|c|c|c|c|c|c|c|}
\hline \multirow[t]{4}{*}{ Species } & \multicolumn{4}{|l|}{ Cove 3} & \multicolumn{4}{|c|}{ Waterhole 10} \\
\hline & \multirow[t]{3}{*}{$\%$ Cov. } & \multirow[t]{3}{*}{ Den. } & \multirow{2}{*}{\multicolumn{2}{|c|}{$\begin{array}{l}\mathrm{NISP}=4651 \\
\text { Matrix }=186 \mathrm{~g}\end{array}$}} & \multirow[t]{3}{*}{$\%$ Cov. } & \multirow[t]{3}{*}{ Den. } & \multirow{2}{*}{\multicolumn{2}{|c|}{$\frac{\mathrm{NISP}=1278}{\text { Matrix }=189 \mathrm{~g}}$}} \\
\hline & & & & & & & & \\
\hline & & & Rel. IP & \% NISP & & & Rel. IP & $\%$ NISP \\
\hline \multicolumn{9}{|l|}{ Trees, Shrubs, Succulents } \\
\hline Ameliachier utahensis & 1.4 & 8 & 1.4 & & & & & \\
\hline Artemisia bigelovii & 15.8 & 76 & 15.8 & 4.5 & & & & 0.2 \\
\hline Atriplex canescens & & & & & 0.3 & 3 & 0.3 & 12.1 \\
\hline Atriplex confertifolia & & & & 0.9 & & & & \\
\hline Coleogyne ramosissima & 12.8 & 73 & 12.8 & 8.9 & 8.8 & 67 & 8.8 & 17.9 \\
\hline Ecinocereus sp. & 0.3 & 2 & 0.3 & & 0.3 & 3 & 0.3 & \\
\hline Ephedra torreyana & & & & & & & & 0.1 \\
\hline Ephedra viridis/cutleri & 6.1 & 10 & 6.1 & 0.7 & 14.1 & 192 & 14.1 & 5.4 \\
\hline Fraxinus anomala & & & & 0.1 & & & & \\
\hline Guterrezia microcephala & & & & & 9.7 & 338 & 9.7 & 4.1 \\
\hline Guterrezia sarothrae & 8.8 & 52 & 8.8 & 4.6 & & & & \\
\hline Isocoma acradenia & & & & 0.1 & & & & \\
\hline Juniperus osteosperma & 38.7 & 10 & 10.9 & 38.7 & 12.3 & 11 & 12.3 & 21.0 \\
\hline Krascheninnikovia lanata & & & & & & & & 1.6 \\
\hline Mahonia fremontii & & & & 0.1 & 6.2 & 5 & 6.2 & 3.4 \\
\hline Opuntia erinacea & 0.05 & 2 & 0.5 & 0.4 & 0.4 & 65 & 2.5 & 19.9 \\
\hline Pinus edulis & 8.22 & 10 & 29.2 & 39.8 & 2.52 & 10 & 6.4 & 7.4 \\
\hline Sclerocactus whipplei var roseas & 0.01 & 2 & 0.3 & & 0.01 & 6 & 0.2 & 0.9 \\
\hline Symphoricarpos longiflorus & 0.03 & 3 & 0.6 & 0.1 & & & & \\
\hline Yucca angustissima & 0.09 & 13 & 2.3 & 0.2 & 0.01 & 2 & 0.1 & 0.5 \\
\hline \multicolumn{9}{|l|}{ Herbs \& Grasses } \\
\hline Abronia sp. & & & & & 0.01 & 5 & 0.1 & \\
\hline Achnatherum hymenoides & 0.02 & 5 & 0.8 & 0.6 & 0.02 & 10 & 0.3 & 2.0 \\
\hline Aristida purpurea & 0.05 & 39 & 6.1 & & 0.09 & 28 & 0.9 & \\
\hline Astragalus sabulonum & & & & & 0.01 & 5 & 0.1 & \\
\hline Bromus tectorum & & & & & 0.02 & 18 & 0.5 & 0.4 \\
\hline Chaenactis steviodes & & & & 0.1 & & & & \\
\hline Chamaesyce fendleri & & & & 0.1 & 0.02 & 18 & 0.5 & \\
\hline Cryptantha sp. & 0.02 & 2 & 0.4 & & 0.01 & 2 & 0.1 & \\
\hline Delphinium sp. & 0.01 & 2 & 0.3 & & & & & \\
\hline Elymus elymoides & & & & & & & & 0.2 \\
\hline \multicolumn{9}{|l|}{ Eriogonum corymbosum } \\
\hline Hesperostipa comata & 0.01 & 3 & 0.5 & & 0.4 & 161 & 4.7 & 0.2 \\
\hline Lappula occidentalis & & & & & & & & 0.2 \\
\hline Lepidium montanum & 0.04 & 8 & 1.4 & 0.1 & 0.14 & 57 & 1.7 & 0.8 \\
\hline Machaeranthera canescens & 0.1 & 2 & 0.6 & 0.3 & & & & 0.8 \\
\hline Phlox hoodii & 0.01 & 3 & 0.5 & & & & & \\
\hline Plantego patagonica & & & & & 0.01 & 13 & 0.3 & \\
\hline Pleuraphis jamesii & & & & & 1.25 & 1052 & 27.5 & \\
\hline \multicolumn{9}{|l|}{ Salsola } \\
\hline Sphaeralcea parviflora & 0.01 & 2 & 0.3 & & 0.01 & 10 & 0.3 & 0.9 \\
\hline Sporobolus contractus & & & & & 0.2 & 73 & 2.2 & 0.1 \\
\hline Vulpia octoflora & & & & & & & & 0.1 \\
\hline Total & 14.86 & 327 & 100 & 100 & 20.31 & 2154 & 100 & 100 \\
\hline
\end{tabular}

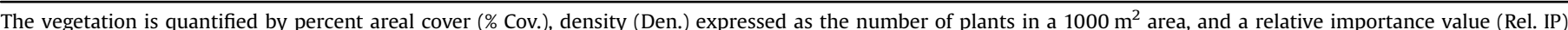

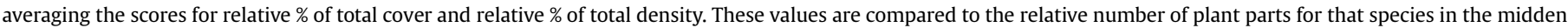

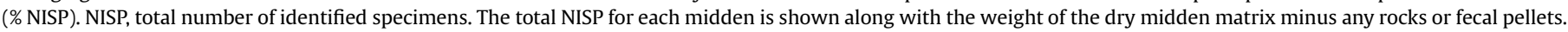
All positive values are rounded up to at least 0.1 for \% NISP and .01 for \% cover.

formed. Indeed, AMS radiocarbon dating of two of these samples, from GS-3 and 5M-1, proved them to be modern contaminants. Light macrofossils such as these can easily blow into fissures within older middens emphasizing the need for either discounting the presence of a few wind-transported macrofossils or verification the age of such taxa using AMS procedures.

\subsection{Post-settlement time period}

Thirteen middens represented the post-settlement, or modern, era. All five sites contained at least one modern midden, while all three middens from Mazuki Point were modern. Six modern middens represented ungrazed sites: one from Gandolf's
Staircase, two from 5381 Mesa, and three from Mazuki Point. Most of these middens were diverse, averaging $21.2 \pm 4.2$ genera/ midden. Most of these middens shared sub-fossils of blackbrush, ephedra, opuntia, rubber rabbitbrush, milkvetch (Astralagus spp.), desert needlegrass (Achnatherum speciosum), Indian rice grass, and cheatgrass. Narrowleaf yucca, Bigelow's sagebrush, fourwing saltbush, and roundleaf buffaloberry were also common. Two middens from Mazuki Point had specimens of filaree (Erodium cicutarium), an invasive exotic, while two middens had plant parts of red brome (Bromus rubens), another invasive exotic, along with cheatgrass. Only two middens contained Utah juniper and only one pinyon pine. However, neither species grows today on Mazuki Point and only Utah juniper grows on 5381 Mesa. All 


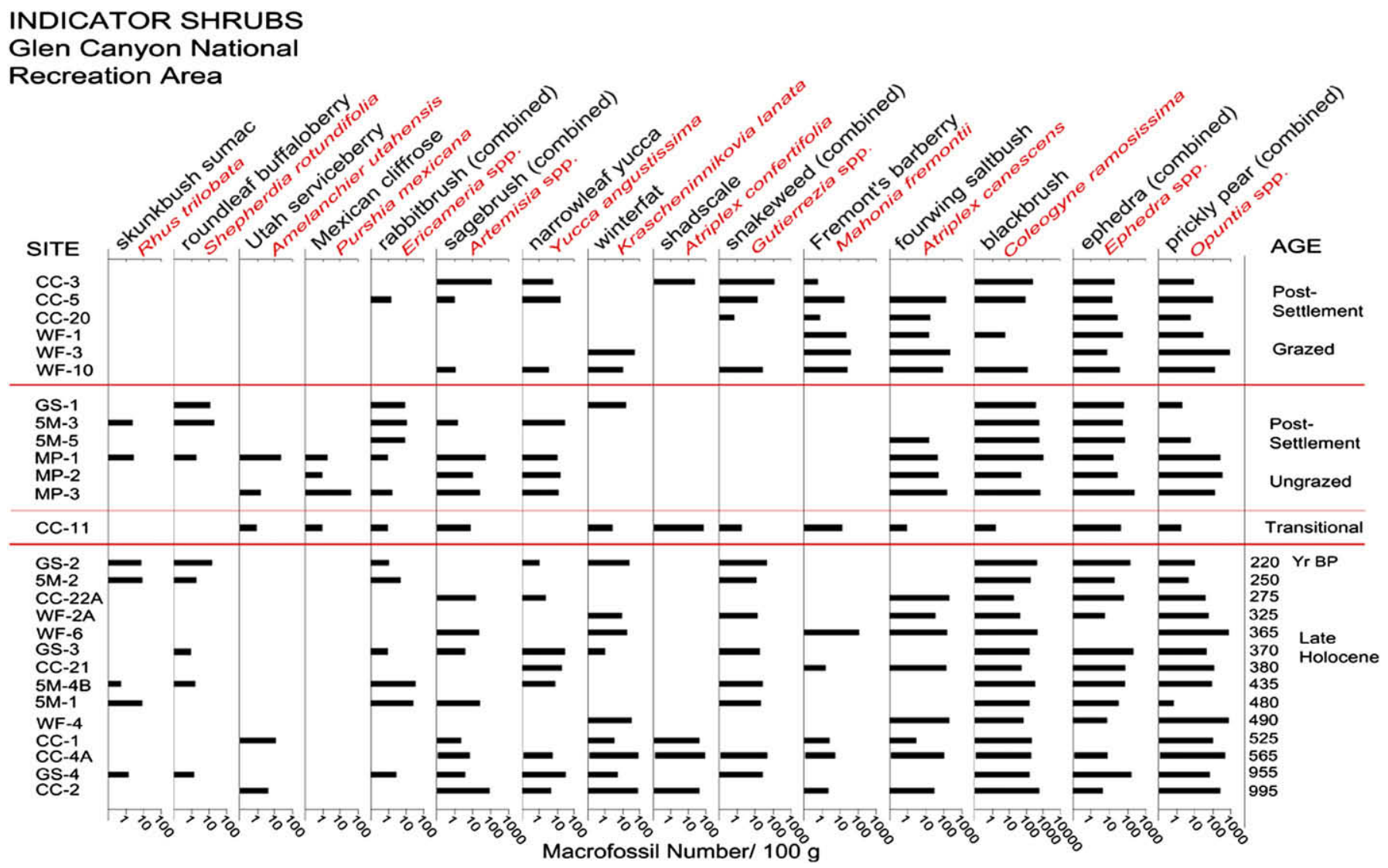

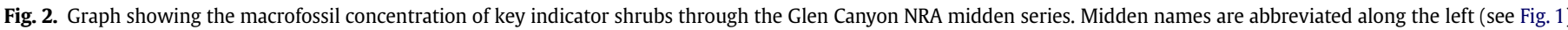
and ages arranged along the right.

of the ungrazed area middens contained at least two native grass species.

Six modern middens were collected from two grazed areas: Cove Canyon (CC-3, CC-5, and CC-20) and Waterhole Flat (WF-1, WF-3, and WF-10). All these middens contained Utah juniper, prickly pear, ephedra, and Fremont's barberry (Mahonia fremontii). Five out of the six contained Indian rice grass, pinyon pine, and fourwing saltbush. Four middens have a species of snakeweed, either Gutierrezia sarothrae or Gutierrezia microcephala. Three middens contained cheatgrass. Plants of interest seen less frequently included rubber rabbitbrush, winterfat, shadscale, native herbs, and native grasses. One midden, CC-5, contained the exotic plant prickly Russian thistle (Salsola tragus). This group of middens had the lowest number of taxa, averaging only $14.5 \pm 6.2$ genera/midden.

\subsection{Pollen analysis}

Pollen was analyzed for 11 middens (Fig. 5). The four postsettlement middens analyzed for pollen are all from grazed areas. Of the arboreal pollen, juniper was abundant in all middens throughout the time series. Some shrub pollen types decreased in counts from pre- to post-settlement eras, including pollen of Chenopodiaceae and Amaranthus spp. (cheno-am pollen type) and prickly pear. Ephedra-type, mountain mahogany-type (Cercocarpus-type), blackbrush, and roundleaf buffaloberry increased during those time period transitions. Sagebrush and Torrey's ephedra-type remained constant.

Several herbs also had abundance switches from the pre- to post-settlement periods. Fishhook cactus-type (Sclerocactus-type) and grass family counts all decreased from pre-settlement to the modern, grazed era. Globemallow (Sphaeralcea spp.) decreased, while ragweed (Ambrosia spp.) remained fairly constant. One modern midden, CC-5, contained high counts of Sporormiella, a dung fungus spore, which is often found in association with cattle dung (Davis et al., 1977, 2002).

\subsection{Species trends}

The midden data (Figs. 2-5) allow examination of species trends as they are affected by grazing through both time and space by the plant macrofossil record, and through time by the pollen record. Changes for many individual species are reflected in the macrofossil records, while the different taxonomic levels represented in the pollen record display broader, often family-level, changes across the landscape.

Fremont's barberry and prickly Russian thistle were more abundant in middens from the grazed sites and times as reflected by both the macrofossil and pollen records. The change in Fremont's barberry was particularly evident in the macrofossil record (Fig. 2). Blackbrush was less concentrated in middens from the grazed sites; a change also somewhat reflected by the pollen record (Fig. 5). Utah serviceberry, roundleaf buffaloberry, and skunkbrush sumac were absent from the middens from the grazed sites, while rabbitbrush was only found in one grazed midden. These taxa are all frequent at the sites ungrazed over both space and time but none were represented in the pollen record.

The most conspicuous change in macrofossils between the grazed and ungrazed sites through both time and space is the frequency of native herbs (Fig. 3) and native grasses (Fig. 4). Some of 


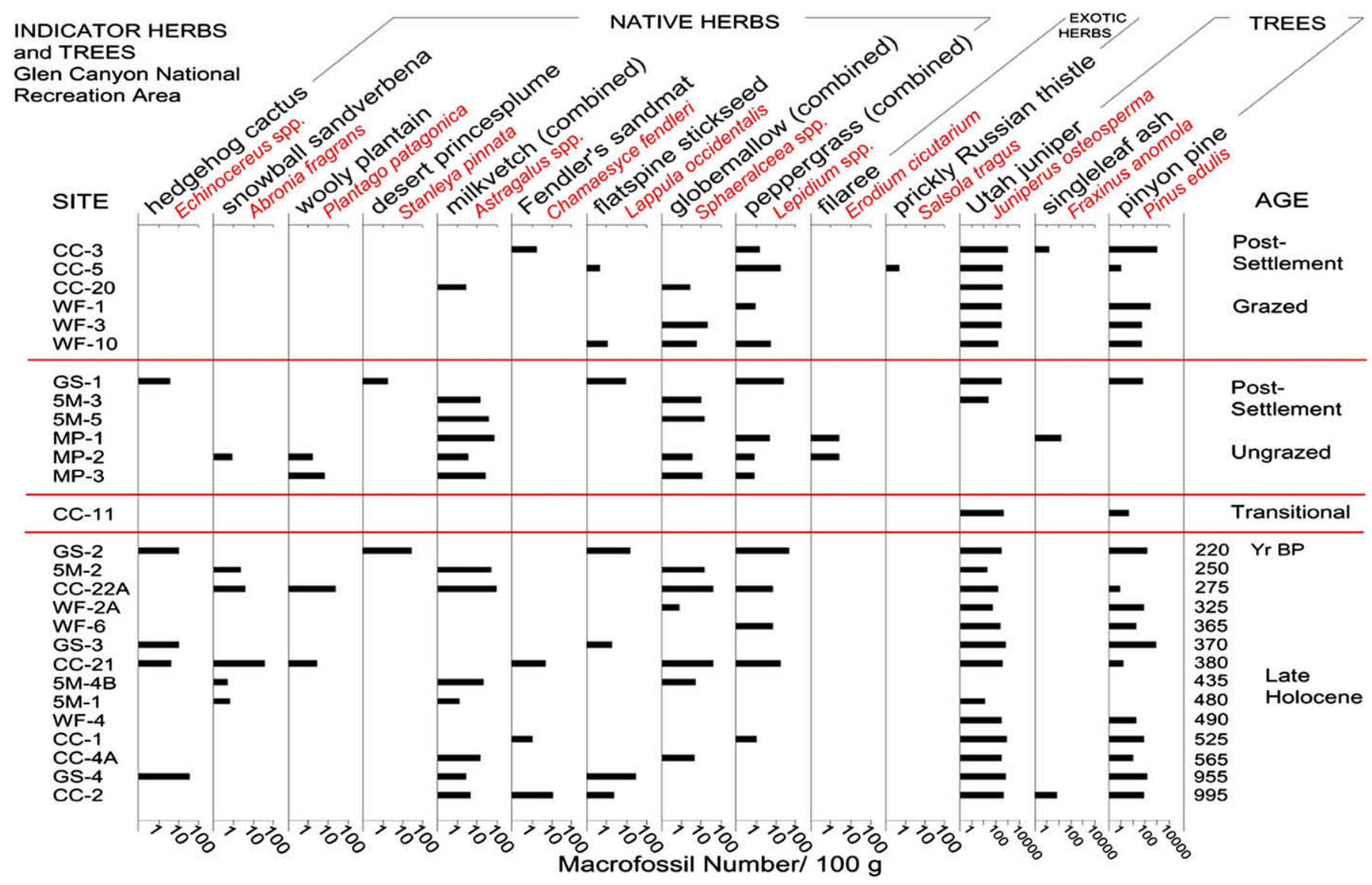

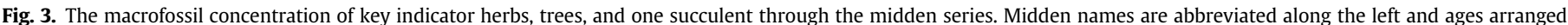
along the right.

these individual taxa are represented only sporadically from the ungrazed sites, but as a group they are far less frequent from the grazed sites. Although many of these taxa are unlikely to be represented in the pollen record, the decreases in pollen of globemallow and the Poaceae family with grazing likely reflect these same trends. The most conspicuous differences for individual species are the abundances of desert needlegrass, galleta grass, and milkvetch in the temporally and spatially ungrazed samples when compared to their total absence in the grazed samples (except for one milkvetch sample). Cheatgrass, an introduced exotic, is also far more frequent on the spatially ungrazed sites.

The records for some taxa suggested a change in either the temporal, spatial, or pollen records that was not replicated in the other series. Winterfat, frequent in the pre-settlement middens, is rare in both the modern grazed and ungrazed middens. Shadscale shows a similar, if less pronounced, trend. These taxa are likely the primary constituents in the cheno-am pollen record showing a similar trend. Snakeweed, a frequent component in the presettlement middens, was only found at the grazed sites.

\subsection{Midden ordinations}

An ordination of all of the middens is shown in Fig. 6. The middens cluster together most closely by site location as illustrated by symbol shape, but not by age or treatment (grazed vs. ungrazed). The middens from the two grazed sites, Cove Canyon (CC) and Waterhole Flat (WF), form one overlapping cluster while the three ungrazed sites, Gandolf's Staircase (GS), Mazuki Point (MP), and 5381 Mesa ( $5 \mathrm{M}$ ), form separate clusters. This ordination shows that the main differences in the midden assemblages are site-to- site differences, reflecting some combination of variability in history, microclimate, geology, soil, or hydrology. It is logical that CC and WF group together, being close in physical proximity on the same stratigraphic level of the Cedar Mesa Sandstone. These siteto-site differences are remarkable in light of fact that every site was selected to be within as similar ranges of elevation, plant community, and substrate type as possible.

This finding highlights one of the fundamental problems with many grazing studies: the assumption of spatial homogeneity among grazed and ungrazed sites (Guenther et al., 2004). Although Gandolf's Staircase is directly in-between the two grazed sites, CC and $\mathrm{WF}$, (Fig. 1), and on the same geologic substrate, it forms a very distinct cluster apart from them. However, it is at a slightly lower stratigraphic level of the Cedar Mesa Sandstone Formation. Apparently, a combination of minor substrate differences, isolation, and/or the reduction of insolation and wind by its surrounding cliffs are sufficient to modify local conditions, resulting in subtle differences in its plant association. Mazuki Point and 5381 Mesa are both much further away on isolated mesa tops with greater wind exposure and underlain by different sandstone geologic units.

The ordination also demonstrates that the age of the midden has little bearing on the clustering. Modern middens are found to be very similar to middens from up to $995 \mathrm{yr}$ BP. This shows that it is acceptable to compare the middens from less than $1000 \mathrm{yr}$ BP to modern middens, and that climatic conditions have not changed drastically enough that the resultant plant assemblage changes are evident in the packrat midden assemblages.

A second ordination eliminates most of the site-to-site variability by graphing only the pre- and post-settlement middens from the most similar sites, CC and WF (Fig. 7). This graph, again, 
INDICATOR GRASSES

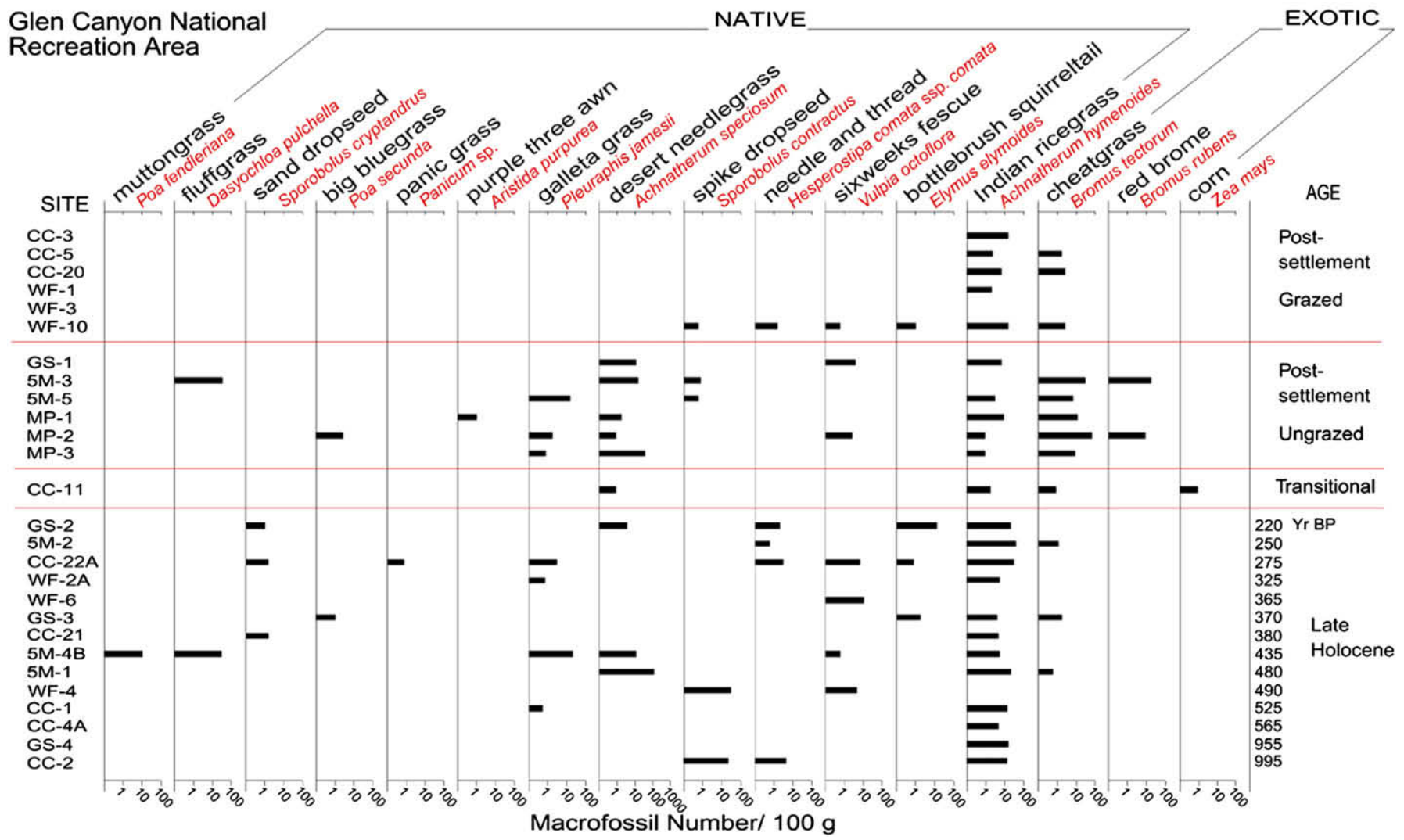

Fig. 4. The concentration of key indicator grasses through the midden series. Midden names are abbreviated along the left and ages arranged along the right.

shows that there are no obvious trends along the axes reflecting middens of different age. This ordination further divides the CC middens into sub-sites, CC-cow shade, CC-cow tank, and CC-500m from tank. WF, CC-cow shade, and CC-cow tank are all intensively grazed in the winter and spring months while CC-500m from tank is further from available water and is only moderately grazed.

In this ordination, pre- and post-grazing middens do become separated. Because there is only one moderately impacted site, CC3 from CC-500m from tank, it is not possible to tell whether intensively and moderately grazed sites cluster separately. That midden, though, does fall to the periphery and is not central in the cluster. CC-11, the transitional midden, also is on the periphery of the cluster.

Fig. 8 represents changing assemblages through time as shown by the arrows. At this enlarged scale, there is a differentiation by age. The middens tend to move up Axis 2, and towards the middle of Axis 1. Although the CC-cow shade middens differ on Axis 1 from the CC-cow tank and CC-500m from tank middens, the grazing treatment seems to draw middens toward the middle of the ordination. The moderately grazed site, CC-500m from tank, shows less movement through ordination space, suggesting that the effect of grazing is not as strong here as with the more intensely grazed sites. These results suggest that grazing resulted in a homogenization of the plant associations; previously different associations became more similar following the grazing.

This homogenization may result from a lowering of diversity in the grazed assemblages and the number of genera identified in each midden type supported this conclusion. The 14 pre-settlement middens and 6 post-settlement, ungrazed middens, contained a more diverse set of genera ( $19.1 \pm 5.4 \& 21.2 \pm 4.2$ genera/midden $)$ than the 6 post-settlement grazed middens $(14.5 \pm 6.2$ genera/ midden). Comparing the modern grazed middens versus the ungrazed middens (pre-settlement $\&$ modern) yielded a significant difference between the groups using a $t$-test $(P=0.046)$.

\section{Discussion}

\subsection{Expected vs. observed changes}

A comparison between abundance of various species in the grazed versus ungrazed middens, summarized by Fisher (2005), supports many of the changes expected from a review of grazing effects literature (Parker, 1972; Stubbendieck et al., 1997; USDA, 1988; Whitson et al., 1991) in at least one of the three measures (macrofossils through time or space, or pollen through time). The results from the different measures were rarely in direct conflict. As expected, many palatable herbs and shrubs had lower values in middens collected from the grazed areas but remained present in the ungrazed areas, such as: native grasses, native herbs, Utah serviceberry, roundleaf buffaloberry, and skunkbush sumac. Fremont's barberry and prickly Russian thistle were more abundant in the grazed middens as expected.

Some might have expected higher numbers of exotic grasses on grazed areas, but our results clearly support the opposite. Cheatgrass and red brome had higher values from post-settlement ungrazed areas suggesting that the winter and spring cattle grazing reduced the frequency these species just as it did the native grasses.

Rabbitbrush (E. nauseosa, recently Chrysothamnus nauseosus) is often expected to increase with grazing, but the identification of these shrubs is complicated by interspecific, and likely intergeneric, hybridization. Also, different subspecies of rabbitbrush have a great range of palatability for cattle (Hanks et al., 1975). The consistent 


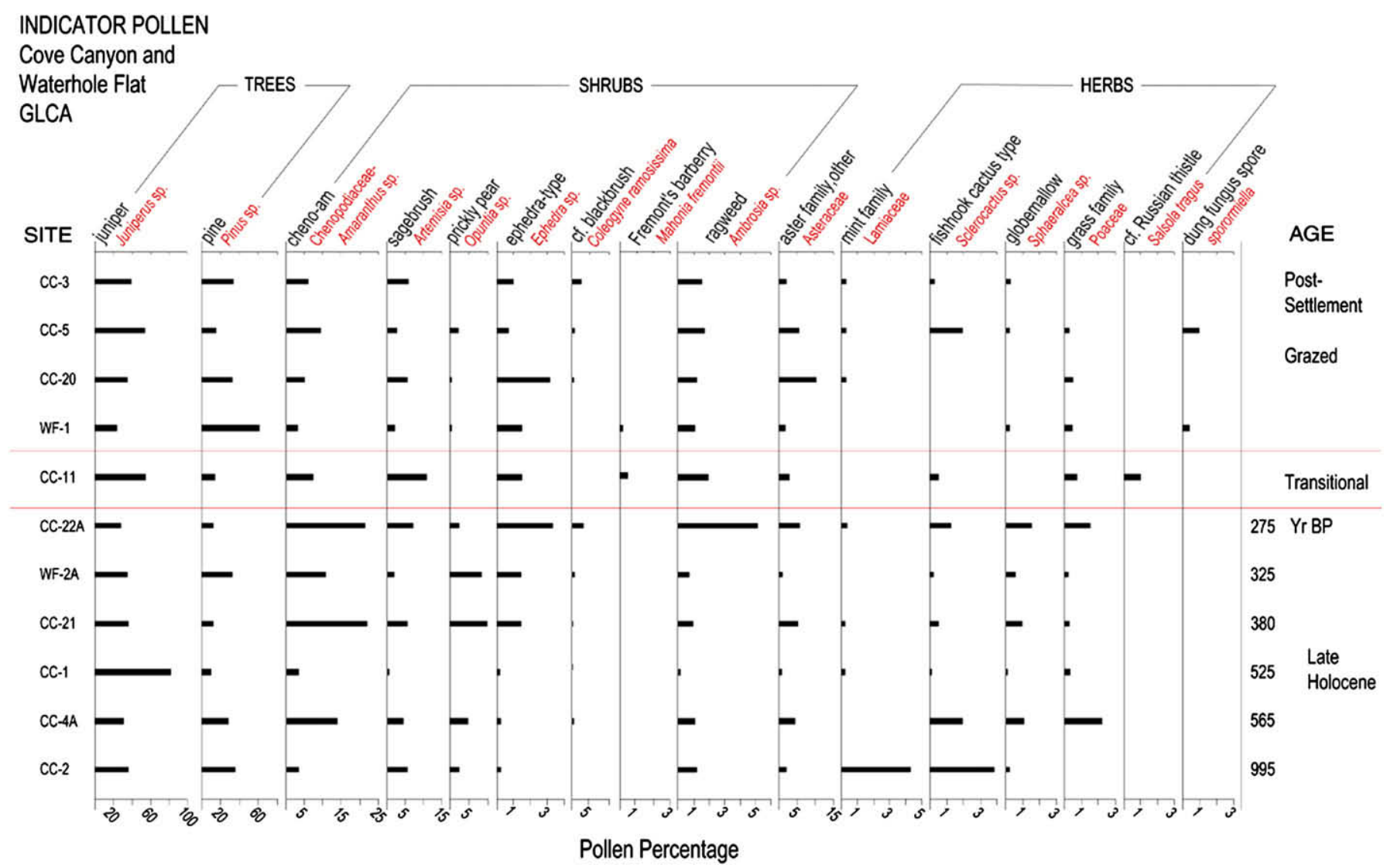

Fig. 5. The percentage of pollen from 11 middens in the midden series (note changing \% scales).

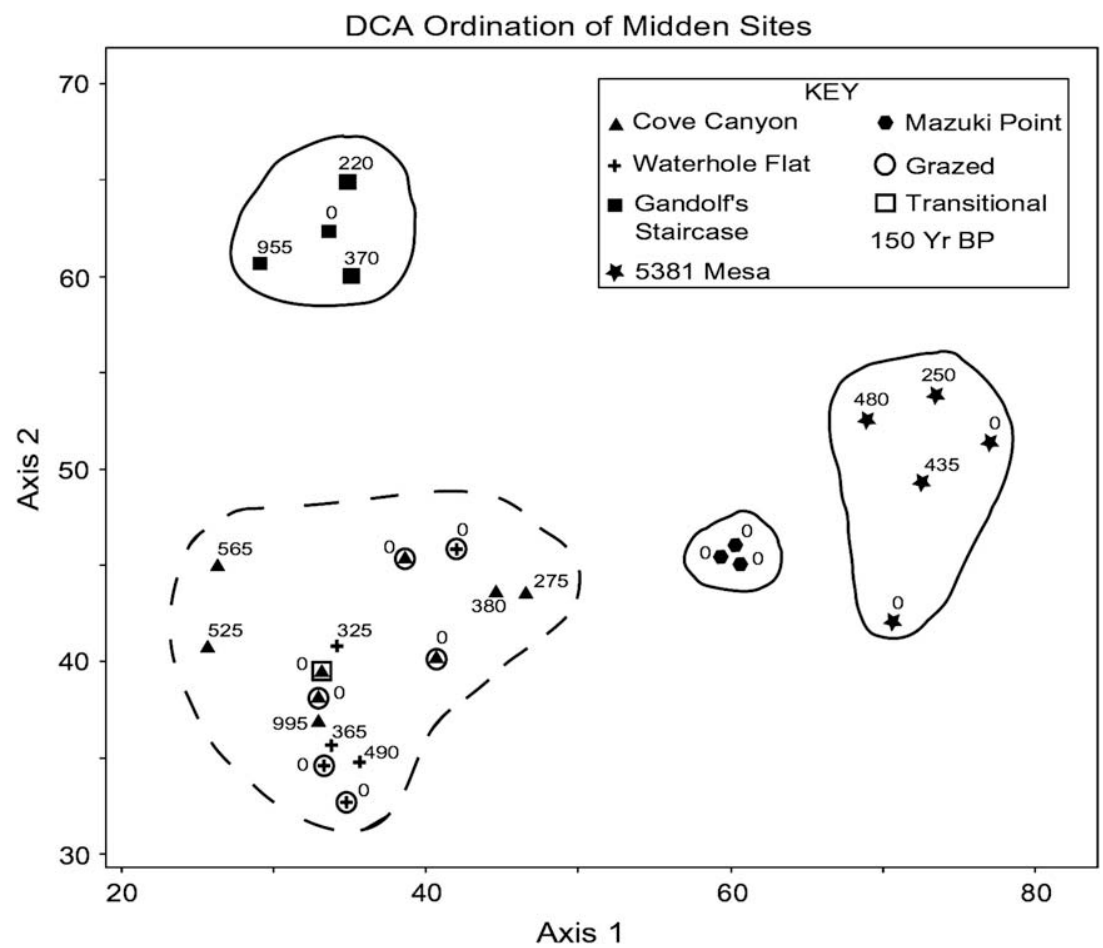

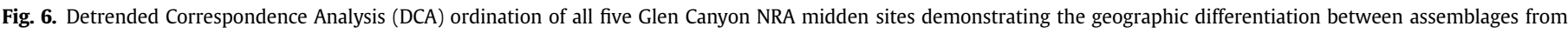
different sites. Samples from the two grazed sites are encircled by the dashed line. Numbers adjacent to the symbols show the age of the assemblages (yr BP). 


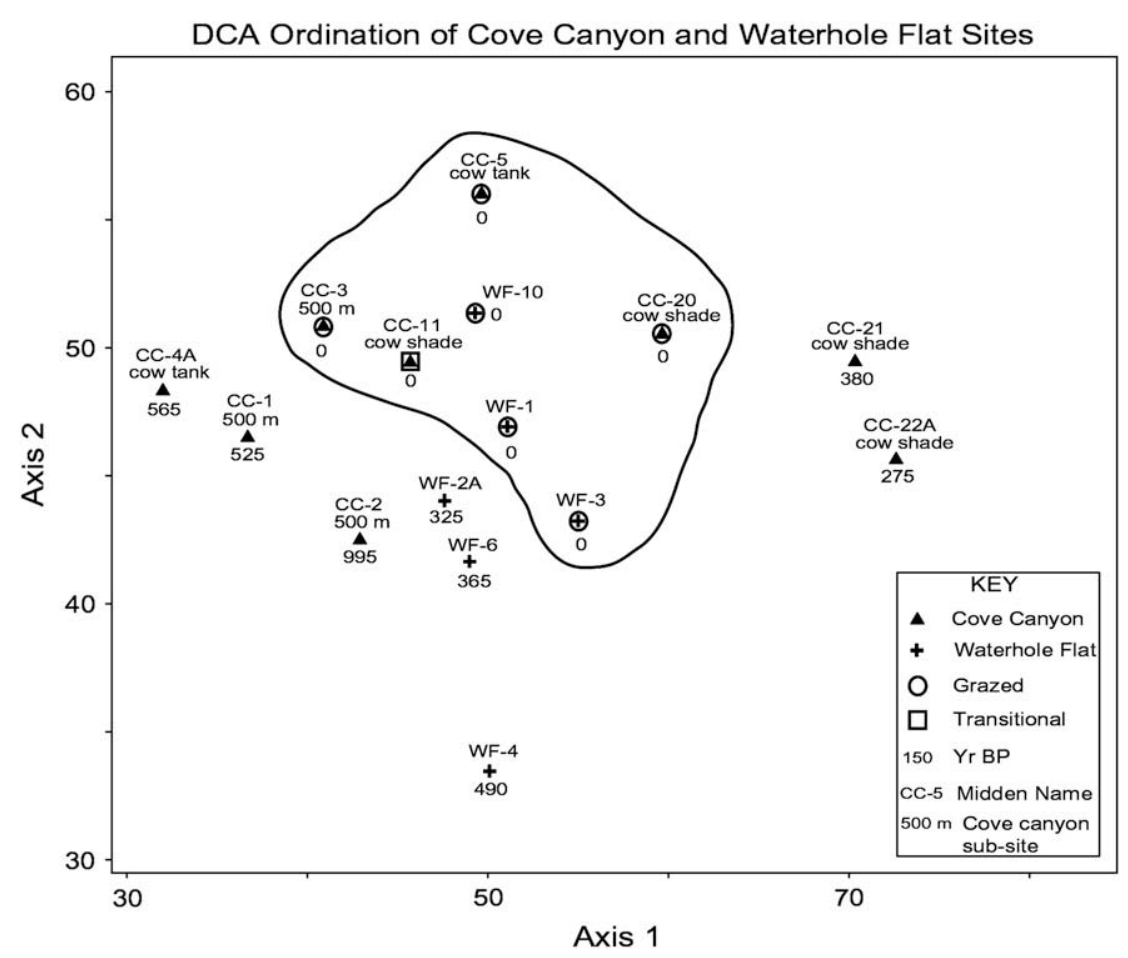

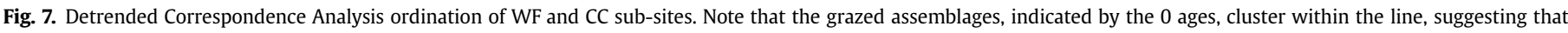
they are less diverse than the older assemblages.

presence of these plant parts in both fossil and ungrazed middens versus only three achenes found in one post-grazing midden from the least impacted grazing site (CC-500m from tank) strongly implies the reduction of these plants from the Ericameria/Chrysothamnus complex from these grazed areas.

Sagebrush and blackbrush became less frequent on grazed sites. Although not highly palatable, these could be a food source of last resort as preferred grasses disappear, and this could cause their decrease. However, this is unlikely since cattle are usually grazed in Glen Canyon NRA only during the less-stressful periods of winter and spring. It is more likely that it has been impacted by trampling since they primarily grow on well-developed soils in this area, or possibly a reflection of early historic sheep and/or goat grazing which could have affected the area (Cole et al., 1997).

Prickly pear and ephedra are two plants that are highly valued by packrats as food items, and also as defensive nesting material.

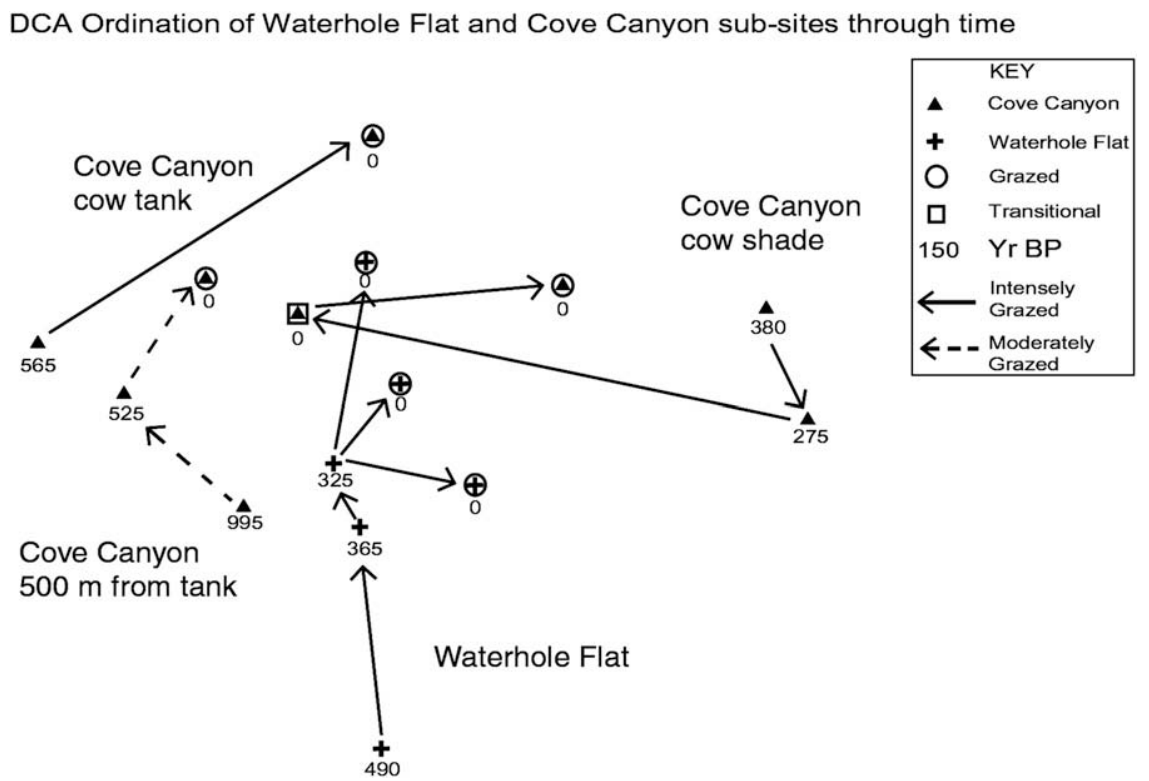

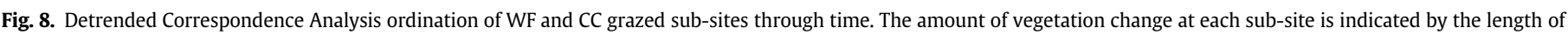
the arrows. 
These plants are likely picked by the packrats selectively over other plants, and are unlikely to be ideal grazing indicators in packrat middens. Both of these plants remained at similar levels through time and space with the macrofossils, even though decreases in their pollen percentages were evident.

\subsection{Plant community change}

Evidence for plant community change is found in long-term studies of historical change (Brown et al., 2001; Mack, 1981) as well as in studies of micro- and macrofossils found in the paleoecological record (Davis and Turner, 1986; Lavoie and Filion, 2001). By looking at past plant communities and assessing the factors that have caused them to change, the characteristics of future communities might be predicted, and undesirable human-caused modifications can potentially be prevented or mitigated.

The human-influenced changes observed in ecosystems of the deserts of western North America range from those affecting a single plant species to those having broad and sweeping community-wide alterations. Grazing can affect native (Cole et al., 1997) and exotic (Bashkin et al., 2003; Knapp, 1996) plants, species richness (Fleischner, 1994; Jones, 2000; Rambo and Faeth, 1999), sex-distribution (Cibils et al., 2000), plant cover (de Soyza et al., 2000), plant composition (Menke and Bradford, 1992), and aboveground (Barrow, 1997) and below-ground (Abbott et al., 1991) plant architecture. Our results supported previous studies that suggest grazing decreases plant species richness.

From the DCA ordinations comparing the different Cove Canyon sub-sites, this study shows that the grazing had the effect of homogenizing the plant assemblages by reducing their spatial variability, and that the moderately grazed areas have changed less dramatically than heavily grazed areas. These results suggest that more moderate grazing had less impact on plant associations than heavier grazing. This has been shown to be true in other studies as well, where light grazing can even have a positive effect on abundance, richness, and diversity of certain species on the landscape (Valone and Kelt, 1999).

Four exotic species, prickly Russian thistle, filaree, cheatgrass, and red brome, were found in the middens. Surprisingly, large amounts of exotics were also found on the relict ungrazed mesas. Because these exotics are wind and avian-dispersed, their high abundance in the ungrazed areas suggests that they are capable of spreading to ungrazed areas and are probably reduced themselves by grazing at critical times.

\subsection{Natural reference conditions in desert grasslands}

Because ecosystem restoration requires returning an area to its "original" condition, it is imperative to know just what this "original" state was. For restorationists, the difference between ecosystem improvements and impacts may be largely one of personal opinion unless this history is known. This is especially important in arid and semi-arid areas such as the arid southwestern U.S. where vegetation recovery is very slow, paleoecological data are poor, and major changes caused by grazing likely occurred during the 19th Century, pre-dating the detailed historical record. Packrat midden research assists with this by showing which species have undergone the largest changes in specific areas.

Complete restoration to historical ecosystems in this region may be impossible due to increasing moisture deficits projected for this region (Seager et al., 2007). These changes will also likely result in an increase the dominance of early successional species and a decline in late successional species (Cole, in press). Nevertheless, knowledge of the historical reference conditions is still imperative. Vegetation change driven by this climate shift cannot be known without an understanding of the rate of recent changes and their starting point.

This study found a high frequency of native grasses and herbs in both the pre-settlement and ungrazed assemblages. When these values are compared to the grazed assemblages, they should serve as a caution to anyone classifying the natural vegetation in desert areas that have undergone a century or more of grazing, even well after that grazing has ceased. Although these areas may currently be shrub-dominated, this likely was not always the case. Regions with abundant 19th Century cattle or sheep industries, before the development of modern water storage and transportation improvements, must have had significant biomass of grasses and herbs in order to remain viable. This transformation from desert grassland to shrub desert must have also affected other natural features as well, such as animal populations and fire frequency (Davis et al., 2002).

Packrat midden series have traditionally been used to reconstruct major shifts in plant associations caused by large-scale climate changes occurring over thousands of years. This study demonstrates that they can also be used to document more subtle vegetation changes such as those brought about over decades to centuries. Our results suggest that unless identical adjacent areas that have never been grazed are available for comparison (a very rare situation), one should be very careful about assuming they know the natural reference conditions for an area.

\section{Conclusions}

The temporal changes of the last 1000 years and changes due to grazing were less significant than the original site-to-site variability in grasslands on sandstone substrates at similar elevations of Glen Canyon NRA. These differences were not necessarily evident through casual observation at the start of the study and all of these areas had originally been mapped as the same desert grassland plant association. These results emphasize the difficulty with assuming spatial homogeneity between sites in a study of this type.

Our results also demonstrate that changes have occurred on the grazeable areas through time, but it remains unknown which of these changes can be attributed to cattle grazing of the late 20th Century versus the possibly more severe cattle and sheep impacts prior to that time. Packrat middens from grazed areas contained far fewer taxa and the plant assemblages were more homogenous.

It is clear from the temporal trends in this data that the grazing had an effect on some plant species which were not apparent on the ungrazed areas. Also, although our results support many of the expected effects of grazing on most species, this was not true for all species. These results caution that just as the plant associations are highly variable from place to place, the effects of grazing can also be variable depending on the grazing species, the density of animals, and the season of grazing.

\section{Acknowledgements}

Valuable field assistance was received from John Cannella, Charles Drost, John Spence, and Tim Graham. Sandy Swift and William Cole assisted in the lab and helpful reviews were received from Dave Mattson, Jeff Lovich and anonymous reviewers. Funding was provided through the USGS/NPS project: "Develop new resource indicators to monitor domestic livestock grazing impacts".

\section{References}

Abbott, M.L., Fraley, L., Reynolds, T.D., 1991. Root profiles of selected cold Desertshrubs and grasses in disturbed and undisturbed soils. Environmental and Experimental Botany 31, 165-178. 
Anderson, R.S., Van Devender, T.R., 1991. Comparison of pollen and macrofossils in packrat (Neotoma) middens: a chronological sequence from the Waterman Mountains of Southern Arizona, U.S.A. Review of Palaeobotany and Palynology $68,1-28$.

Bailey, G., Bailey, R.G., 1986. A History of the Navajos: The Reservation Years. School of American Research Press, Santa Fe, NM, 360 pp.

Barrow, J.R., 1997. Natural asexual reproduction in fourwing saltbush Atriplex canescens (Pursh) Nutt. Journal of Arid Environments 36, 267-270.

Bashkin, M., Stohlgren, T.J., Otsuki, Y., Lee, M., Evangelista, P., Belnap, J., 2003. Soil characteristics and plant exotic species invasions in the Grand Staircase-Escalante National Monument, Utah, USA. Applied Soil Ecology 22, 67-77.

Betancourt, J.L., Van Devender, T.R., Martin, P.S. (Eds.), 1990. Packrat Middens: The Last 40,000 Years of Biotic Change. University of Arizona Press, Tucson.

Bowers, J.E., Webb, R.H., Pierson, E.A., 1997. Succession of Desert plants on debris flow terraces, Grand Canyon, Arizona. Journal of Arid Environments 36, 67-86.

Brown, J.H., Whitham, T.G., Ernest, S.K.M., Gehring, C.A., 2001. Complex species interactions and the dynamics of ecological systems: long-term experiments. Science 293, 643-646.

Cibils, A.F., Swift, D.M., Hart, R.H., 2000. Gender-related differences of shrubs in stands of Atriplex canescens with different histories of grazing by cattle. Journal of Arid Environments 46, 383-396.

Cole, K.L., 1990. Reconstruction of past desert vegetation along the Colorado River using packrat middens. Palaeogeography, Palaeoclimatology, and Palaeoecology 76, 349-366.

Cole, K., Henderson, N., Shafer, D., 1997. Holocene vegetation and historic grazing impacts at Capitol Reef National Park reconstructed using packrat middens. Great Basin Naturalist 57, 315-326.

Cole, K., Vegetation response to early Holocene warming, an analog for current and future changes. Conservation Biology, in press.

Davis, O.K., Kolva, D.A., Mehringer Jr., P.J., 1977. Pollen analysis of Wildcat Lake, Whitman County, Washington: the last 1000 years. Northwest Science 51, 13-30.

Davis, O.K., Turner, R.M., 1986. Palynological evidence for the historic expansion of juniper and desert shrubs in Arizona, U.S.A. Review of Palaeobotany and Palynology 49, 177-193.

Davis, O.K., Minckley, T., Moutoux, T., Jullz, T., Kalin, B., 2002. The transformation of Sonoran Desert wetlands following the historic decrease of burning. Journal of Arid Environments 50, 393-412.

de Soyza, A.G., Van Zee, J.W., Whitford, W.G., Neale‘, A., Tallent-Hallsel, N., E Herrick, J., Havstad., K.M., 2000. Indicators of Great Basin rangeland health. Journal of Arid Environments 45, 289-304.

Fægri, K., Iversen, J., 1989. Textbook of Pollen Analysis. John Wiley \& Sons, New York.

Fisher, J., 2005. Using Packrat Middens to assess how Grazing Influences Vegetation Change in Glen Canyon National Recreation Area, Utah. M.S. Thesis, Northern Arizona University.

Fisher, R.F., Bourn, C.N., Fisher, W.F., 1995. Opal phytoliths as an indicator of the floristics of prehistoric grasslands. Geoderma 68, 243-255.

Fleischner, T., 1994. Ecological costs of livestock grazing in western North America. Conservation Biology 8, 629-644.

Flowers, S., 1959. Vegetation of Glen Canyon. In: Woodbury, A.M. (Ed.), Ecological Studies of Flora and Fauna in Glen Canyon. University of Utah Anthropological Papers No 40 (Glen Canyon Series No. 7). University of Utah Press, Salt Lake City, Utah, pp. 21-61.

Gauch, H., 1982. Multivariate Analysis in Community Ecology. Cambridge University Press.

Guenther, D., Stohlgren, T.J., Evangelista, P., 2004. A comparison of a near-relict site and a grazed site in a pinyon-juniper community in the Grand Staircase-Escalante National Monument, Utah. In: van Riper III, C., Cole, K.L. (Eds.), The Colorado Plateau: Cultural, Biological, and Physical Research. The University of Arizona Press, Tucson, Arizona, pp. 153-162.

Hanks, D.L., McArthur, E.D., Plummer, A.P., Giunta, B.C., Blauer, A.C., 1975. Chromatographic recognition of some palatable and unpalatable subspecies of rubber rabbitbrush in and around Utah. Journal of Range Management 28, $144-148$.

Johnson, W.G., Sharpe, S.E., Bullard, T.F., Lupo, K., 2005. Characterizing a first occurrence of bison deposits in southeastern Nevada. Western North American Naturalist 65, 24-35.

Jones, A., 2000. Effects of cattle grazing on North American arid ecosystems: a quantitative review. Western North American Naturalist 60, 155-164.

Knapp, P.A., 1996. Cheatgrass (Bromus tectorum L.) dominance in the Great Basin desert. Global Environmental Change 6, 37-52.

Lavoie, M., Filion, L., 2001. Holocene vegetation dynamics of Anticosti Island, Quebec, and consequences of remoteness on ecological succession. Quaternary Research 56, 112-127.

Lovich, J.E., Bainbridge, D., 1999. Anthropogenic degredation of the southern California desert ecosystem and prospects for natural recovery and restoration. Environmental Management 24, 309-326.

Mack, R.N., 1981. Invasion of Bromus tectorum L. into western North America: an ecological chronicle. Agro-Ecosystems 7, 145-165.

Mead, J.M., Agenbroad, L.D., Davis, O.K., Martin, P.S., 1986. Dung of Mammuthus in the Arid Southwest, North America. Quaternary Research 25, 121-127.

Mead, J.M., Agenbroad, L.D., 1992. Isotope dating of Pleistocene dung deposits from the Colorado Plateau, Arizona and Utah. Radiocarbon 34, 1-20.

Menke, J., Bradford, G.E., 1992. Rangelands. Agriculture, Ecosystems and Environment 42, 141-163.

National Park Service, 1999. Grazing management plan. Glen Canyon National Recreation Area. U.S. Department of Interior.

Parker, K.F., 1972. An Illustrated Guide to Arizona Weeds. University of Arizona Press, Tucson, AZ.

Rambo, J.L., Faeth, S.H., 1999. Effect of vertebrate grazing on plant and insect community structure. Conservation Biology 13, 1047-1054.

Seager, R., Ting, M.F., Held, I., Kushnir, Y., Lu, J., Vecchi, G., Huang, H.P., Harnik, N. Leetmaa, A., Lau, N.C., Li, C.H., Velez, J., Naik, N., 2007. Model projections of an imminent transition to a more arid climate in southwestern North America. Science 316, 1181-1184

Savage, M., Swetnam, T.W., 1990. Early 19th-century fire decline following sheep pasturing in a Navajo ponderosa pine forest. Ecology 71, 2374-2378.

Spaulding, W.G., Betancourt, J., Croft, L., Cole, K.L., 1990. Packrat Middens: Their composition and methods of analysis. In: Betancourt, J., Van Devender, T., Martin, P.S. (Eds.). The University of Arizona Press, Arizona, pp. 59-84.

Spence, J.R., Romme, W.R., Floyd-Hanna, L., Rowlands, P.S., 1995. A preliminary vegetation classification for the Colorado Plateau. In: van Riper III, C. (Ed.), Proceedings of the Second Biennial Conference of Research in Colorado Plateau National Parks. Trans. Proc. Ser. NPS/NRNAU/NRTP-95/11, pp. 193-213.

Stubbendieck, J., Hatch, S.L., Butterfield, C.H., 1997. North American Range Plants. University of Nebraska Press, Lincoln, NE.

Stuiver, M., Reimer, P.J., 1993. A radiocarbon calibration program. Radiocarbon 35 , 215-230.

Nowak, R.S., Nowak, C.L., Tausch, R.J., 2000. Probability that a fossil absent from a sample is also absent from a paleolandscape. Quaternary Research 54,144-154.

Topping, G., 1997. Glen Canyon and the San Juan Country. University of Idaho Press, Moscow, ID.

Tuhy, J.S., MacMahon, J.A., 1988. Vegetation and relict communities of Glen Canyon National Recreation Area. Final Report to the National Park Service. Glen Canyon National Recreation Area, Arizona.

Underhill, R.M., 1971. Red Man's America. University of Chicago Press, Chicago, IL

United States Department of Agriculture, 1988. Range Plant Handbook. Dover Publications, New York.

Valone, T.J., Kelt, D.A., 1999. Fire and grazing in a shrub-invaded arid grassland community: independent or interactive ecological effects? Journal of Arid Environments 42, 15-28.

Whitson, T.D., Burrill, L.C., Dewey, S.A., Cudney, D.W., Nelson, B.E., Lee, R.D., Parker, R., 1991. Weeds of the West. University of Wyoming Press, Jackson, WY. 